\title{
Detection of Antibiotic Residue from Shrimp Ponds and Their Environment in East Java Province, Indonesia
}

\author{
Hari Suprapto, L. Sulmartiwi, and Sudarno \\ fisheries faculty, Airlangga University, Surabaya, Indonesia \\ Correspondence to: supraptohari@yahoo.com
}

\begin{abstract}
Hari Suprapto, L. Sulmartiwi, and Sudarno. 2015. Detection of Antibiotic Residue from Shrimp Ponds and Their Environment in East Java Province, Indonesia. Aquacultura Indonesiana, 16 (1): 29-32. Indonesia shrimp products are often rejected by foreign countries due to high antibiotic content, whereas a few years ago Japan and European countries are set $0.05 \mathrm{ppb}$ permitted to consume by the people, but now the restriction will become smaller, which is $0.1 \mathrm{ppb}$. Some farmer have topped using antibiotics but the residues were still found in fish flesh. Possible origin of the antibiotic is from environment because residues are still exist in the mud, water organism which lives in the pond. Samples originating from shrimp, mud, water and other biota were examined. The purpose of this study was to determine the origin of antibiotic present in the cultivation or farming system that does not use antibiotics in shrimp production.: a. Antibiotics obtained from ponds in the Tuban area is $1.8 \mathrm{mg} / \mathrm{L}$ (mud), $0.8 \mathrm{mg} / \mathrm{L}$ (water) and 2.1 (biota). b. Antibiotics obtained from ponds in Gresik were $0.6 \mathrm{mg} / \mathrm{L}$ (mud), $0.3 \mathrm{mg} / \mathrm{L}$ (water) and 1.2 (biota). c. Antibiotics obtained from ponds in the area of Situbondo are $0.3 \mathrm{mg} / \mathrm{L}$ (mud), $0.1 \mathrm{mg} / \mathrm{L}$ (water) and 0.6 (biota). d. a. Antibiotics obtained from ponds in the area are $0.3 \mathrm{mg} / \mathrm{L}$ Probolinggo (mud), $0.2 \mathrm{mg} / \mathrm{L}$ (water) and $0.6 \mathrm{mg} / \mathrm{L}$ (biota).
\end{abstract}

Keywords : Antibiotic; Environment; Pond; Shrimp

\section{Introduction}

Rejection of Indonesian shrimp products by some European countries and Japan occurred few years ago due to high antibiotic content. Previously the residue limit was $0.05 \mathrm{ppb}$ but today $0.001 \mathrm{ppb}$. The use of vaccine to prevent the disease is recommended rather than the use of antibiotics. Antibiotics should be stopped because it could cause some excesses of bad health and the environment. Initially antibiotic is used to prevent diseases caused by bacteria, especially for the luminous vibriosis in large scale of farming, oxytetracycline, oxolinic acid, chloramphenicol and furazolidone are used through the feed. In the Philippines they used nitrofurans, erythromycin and sulfa drugs in shrimp culture (Baticados et al., 1990; Cobello, 2006). On salmon farming in British Columbia, Canada in 2000, antibiotics residues in salmon flesh are $0.1 \mathrm{mg} / \mathrm{L}$ (Paone, 2000). Aso reported that crab consumed food remains and salmon faeces contained residue of Further reported that crab eating food remains and feces salmon containing residues Oxytetracycline of 0.8 and $3.8 \mathrm{mg} / \mathrm{L}$. Bjorklund et al. (1990) reported that in Finland, although he did not perform measurements, antibiotic residues in wild fish and sediments were detected from the intestine of fish and also a lot of isolated bacteria resistant to antibiotics. Aeromonas salmonicida causes furunculosis is also resistant to Romet-30, tetracycline, sulfa drugs, trimethoprim, and oxytetracycline Tribrissen (Paone, 2000). Spanggaard et al. (1993) reported that many bacteria in fresh water resistant to antibiotics in Denmark. Nygaard et al. (1992) also reported the use of oxytetracycline and oxolinic acid causing bacteria resistant to antibiotics. Furthermore Leano et al. (1999) reported that Vibrio spp. and Aeromonas spp. isolated from fish and shrimp were resistant to streptomycin but sensitive to oxolinic acid. Now a lot of bacteria are resistan to more than one antibiotic. Vibrio harveyi and Vibrio are the most frequent isolated (Peterson et al., 2002; Tendencia and de la Pena, 2001). The objective of this experiment is to find the sources of antibiotics contaminant in the farm, because according to farmers they had stopped the antibiotics application, but the residue is still found in fish carcasses.

\section{Materials and Methods}

\section{Sampling of water, mud and other biota}

Water, mud and organism from suspected pond contained antibiotic residues were collected. A total of $100 \mathrm{~mL}$ of water was taken and then poured into a dark bottle, sealed and stored at room temperature, $100 \mathrm{~g}$ of mud was taken and put into wide-mouthed dark bottles, while other organisms used as the samples were stored at are 
used as the sample will be stored in the $-80^{\circ} \mathrm{C}$ to avoid spoilage. Prior to the analysis, the biota is tawed at room temperature.

\section{Antibiotics (Chloramphenicol)}

Chloramphenicol was analyzed according to Thomson (1966) and Horwitz (1980). Briefly, cuticle and the head taken from 3 pieces of shrimp of each sample then weighted, crushed and mixed with 4 volumes of $0.1 \mathrm{M} \mathrm{KH}_{2} \mathrm{PO}_{4}$ buffer, $\mathrm{pH} 4.5$ sterile. Half of the buffer is poured to the shrimp in the mixer, blended for $10 \mathrm{sec}$ in a low speed and $10 \mathrm{sec}$ in high speed. The other half is blended for $10 \mathrm{sec}$ of low speed to avoid foaming. The mixture was then centrifuged in $50 \mathrm{~mL}$ tubes for $20 \mathrm{~min}$ at $10,000 \mathrm{rpm}$ at $4^{\circ} \mathrm{C}$, removed the debris material. Supernatant was transferred into a clean, sterile tube and its volume is measured. Supernatant will be devided in two parts, not diluted and diluted with ratio of $1: 3$ with $0.1 \mathrm{M}$ $\mathrm{KH}_{2} \mathrm{PO}_{4}$ buffer, $\mathrm{pH}$ 4.5. Blended and then washed with a half volume of $0.1 \mathrm{M} \mathrm{KH}_{2} \mathrm{PO}_{4}$ buffer, $\mathrm{pH}$ 4.5 for $10 \mathrm{sec}$ in low-speed, stored separately.

Standard curve prepared by using shrimp homogenate without using Chloramphenicol, but using $0.1 \mathrm{~N}$ to final concentration of oxytetracycline (OTC) by $0.1,0.2,0.4,0.8$ and $1.6 \mathrm{mg} / \mathrm{mL}$ OTC. A total of $0.4 \mathrm{mg} / \mathrm{mL}$ OTC is used as a control. Each of a total 18 wells for each standard curve and the 18 wells for reference. Zone size was measured and then compared with reference (control). A reference obtained from an average of 90 wells. Rectification zone size obtained from the increase or decrease the difference between the average sizes for the reference zone which same concentration and average size of the grand reference zone. Suspension of spores of Bacillus cereus (ATCC No. 11 778) prepared in antibiotic medium A (Nifco, Detroit Michigan) on agar plate. Aliquots $(200 \mathrm{~mL})$ was used to test the cylinder is placed in stainless steel, 6 cylinder for each plate, and 3 plates for each test. Nine wells of each shrimp homogenates prepared, as well as references there are 9 wells $(0.4 \mathrm{~g}$ Chloramphenicol $/ \mathrm{mL})$. Zone of inhibition resulting from dilution of shrimp homogenates were then compared with the references above, the results were then calculated by dilution of the homogenate of shrimp that references a result close to the concentration. Total Chloramphenicol in shrimp $(\mathrm{g})$ is calculated by multiplying the concentration of the tested suspension with total volume $(\mathrm{mL})$ of supernatant. Chloramphenicol in the washing water $(\mathrm{g})$ is added to the total homogenate to obtain the number of Chloramphenicol entirely. Amount is then divided by the total weight of shrimp meat to get g Chloramphenicol in shrimp meat.

\section{Results and Discussion}

Organic matter and excessive shrimp feed will dissolve in water and will accumulate in pond bottom. Excessive organic material will cause problems in the ecosystem of brackishwater pond ecosystem because the excessive of organic matter is the habitat of several pathogens bacteria and will spend the oxygen. Excessive feeding may cause the elevation of $\mathrm{NH}_{3}-\mathrm{N}$ and $\mathrm{NO}_{2}$ in the pond. Some plants and animals can absorb ammonia in the water; they can serve as a biological filter. Most farmers used biofilter such as mussels, milkfish, tilapia or mullet with density of 3 pieces of fish $/ \mathrm{m}^{2}$ and. Vibrio bacteria will thrive in water containing a high organic matter (Austin and Austin, 1988) as well as Aeromonas. Organic material causing plankton blooming and interfere growth of fish and shrimp. Water containing high organic matter needs to be reduced by draining the ponds. This pond functions as a reduction of organic matter from water conservancy shrimp because of abundant organic material to be used by plankton to grow and as the main meal of tilapia. Ammonia and some other gases can partially evaporate in the aerated pond. In addition, to the suspended matter will be deposited in these ponds. Biological filter is not able to remove the solids present in the water, but the point is to change harmful substances such as ammonia into harmless substances such as nitrate. For this purpose few bacteria such as Nitrosomonas sp. can be added to help the nitrification process in the water. The main biological filter is an autotrophic bacterium, although algae, yeast and protozoa and other small animals sometimes help turn waste from the body of water. Soil has an important role in shrimp aquaculture, and almost all type of land is suitable for shrimp farming. Soil contains high organic matter is not suitable for aquaculture due to the decomposition of organic matter requires a lot of oxygen. The results of the analysis use chromatography presented in the Table 1 .

Table 1. showed that in Gresik ponds, mud, water and crabs as ponds organisme contains of antibiotics chloramphenicol. The crabs contains antibiotic much higher than in the mud and water. Initially antibiotic was used to prevent diseases caused by bacteria, such as luminous 
Vibriosis shrimp culture. Antibiotics were administered via the feed (medicated feed). In other countries such as the Philippines, antibiotics used in shrimp farming are nitrofurans, erythromycin, and sulfa drugs (Baticados et al., 1990; Primavera et al., 1993) and several other drugs. Uncontrolled use of antibiotics will left the residue in fish and the environment. For example, in fish farming in British Columbia, Canada in 2000, residues of antibiotics in salmon flesh is $0.1 \mathrm{mg} / \mathrm{L}$ (Paone, 2000). This residue also found in several places in East Java with range from 1-2 $\mathrm{mg} / \mathrm{L}$. In dry season antibiotic concentration in some place is high.

Crab eats feed remaining and fish faeces may contains residues of oxytetracycline 0.8 and $3.8 \mathrm{mg} / \mathrm{L}$. Bjorklund et al. (1990) reported that in Finland, although he did not perform measurements of antibiotic residues in wild fish, from sediments and intestine of fish but a lot of resistant antibiotics bacteria can be isolated. Aeromonas salmonicida causes furunculosis is also resistant to Romet-30, tetracycline, sulfa drugs, trimethoprim, and oxytetracycline Tribrissen (Paone, 2000). Spanggaard et al. (1993) reported that many bacteria in fresh water resistant to antibiotics in Denmark. Nygaard et al. (1992) also reported the use of oxytetracycline and oxolinic acid causes the bacteria resistant to other antibiotics. Table 2. Antibiotic analytical results from samples from the area Tuban June-
October.

The antibiotic analytical results from samples from the area Tuban (Table 2.) showed that same as Gresik, mud, water and crabs may contains the chloramphenicol. Furthermore Leano et al. (1999) reported that Vibrio spp. and Aeromonas spp. isolated from fish and shrimp were resistant to streptomycin but sensitive to acid oxolinic. Now a lot of bacteria were resistant to more than one antibiotic. Vibrio harveyi and Vibrio spp. and other species are the most frequent isolated (Tendencia and de la Pena, 2001). The use of drug for cultivation in the USA should get permission from the FDA's Center for Veterinary Medicine. Drug generally used mixed in feed, and it supposed $75 \%$ the fish can use it and not mostly discharged into the environment. So the case like in ornamental fish not happened. Ornamental fish are closer to humans will transmit the bacteria that were resistant to more human. Indiscriminate use of antibiotics in Equador, which will cause outbreak of Vibrio cholerae in the USA. Which are resistant bacteria can be transmitted from fish to human. Table 3 . Antibiotic analytical results from samples from the area Pasuruan June-October. Results of antibiotic analysis from Probolinggo (JuneOctober) see Table 4.

Table 1. Results of antibiotic analysis from Gresik (June-October, 2011)

\begin{tabular}{lllll}
\hline Sample & Sample quantity & Antibiotic concentration & Antibiotic in feed & Antibiotic \\
\hline Mud & $100 \mathrm{~g}$ & $0.6 \mathrm{mg} / \mathrm{L}$ & $1000 \mathrm{mg} / \mathrm{kg}$ & Chloramphenicol \\
Water & $100 \mathrm{~mL}$ & $0.3 \mathrm{mg} / \mathrm{L}$ & $1000 \mathrm{mg} / \mathrm{kg}$ & Chloramphenicol \\
Pond organism/crabs & 2 & $1.2 \mathrm{mg} / \mathrm{L}$ & $1000 \mathrm{mg} / \mathrm{kg}$ & Chloramphenicol \\
\hline
\end{tabular}

Table 2. Results of antibiotic analysis from Tuban (June-October, 2011)

\begin{tabular}{lllll}
\hline Sample & Sample quantity & Antibiotic concentration & Antibiotic in feed & Antibiotic \\
\hline Mud & $100 \mathrm{~g}$ & $1.8 \mathrm{mg} / \mathrm{L}$ & $1000 \mathrm{mg} / \mathrm{kg}$ & Chloramphenicol \\
Water & $100 \mathrm{~mL}$ & $0.8 \mathrm{mg} / \mathrm{L}$ & $1000 \mathrm{mg} / \mathrm{kg}$ & Chloramphenicol \\
$\begin{array}{l}\text { Pond } \\
\text { organism/crabs }\end{array}$ & 2 & $2.1 \mathrm{mg} / \mathrm{L}$ & $1000 \mathrm{mg} / \mathrm{kg}$ & Chloramphenicol \\
\hline
\end{tabular}

Table 3. Results of antibiotic analysis from Pasuruan (June-October, 2011)

\begin{tabular}{lllll}
\hline Sample & Sample quantity & Antibiotic concentration & Antibiotic in feed & Antibiotic \\
\hline Mud & $100 \mathrm{~g}$ & $0.3 \mathrm{ppb}$ & $1000 \mathrm{mg} / \mathrm{kg}$ & Chloramphenicol \\
Water & $100 \mathrm{~mL}$ & $0.1 \mathrm{ppb}$ & $1000 \mathrm{mg} / \mathrm{kg}$ & Chloramphenicol \\
Pond organism/crabs & 2 & $0.6 \mathrm{ppb}$ & $1000 \mathrm{mg} / \mathrm{kg}$ & Chloramphenicol \\
\hline
\end{tabular}

Table 4. Results of antibiotic analysis from Probolinggo (June-October, 2011)

\begin{tabular}{lllll}
\hline Sampel & Sample quantity & Antibiotic concentration & Antibiotic in feed & Antibiotic \\
\hline Mud & $100 \mathrm{~g}$ & $0.3 \mathrm{ppb}$ & $1000 \mathrm{mg} / \mathrm{kg}$ & Chloramphenicol \\
Water & $100 \mathrm{~mL}$ & $0.2 \mathrm{ppb}$ & $1000 \mathrm{mg} / \mathrm{kg}$ & Chloramphenicol \\
Pond & 2 & $0.6 \mathrm{ppb}$ & $1000 \mathrm{mg} / \mathrm{kg}$ & Chloramphenicol \\
organism/crabs & & & & \\
\hline
\end{tabular}


Only 5 kind of drugs are legal in the USA are: oxytetracycline $\mathrm{HCl}$ (Terramycin 10), sulfamerazine, and drug combinations containing sulfadimethozine and ormetoprim (Romet-30). Although it found a problem if not used antibiotics in aquaculture National Seafood HACCP Alliance for Training and Education Compendium (USA) "growth" is one reason why farmer use of antibiotics. Antibiotics affect reproduction, growth and prevent disease. Total antibiotic that is used for the production of cattish USA in an estimated between 126,000-252,000 Lb. Antibiotic used for the treatment of enteric septicemia of Catfish (ESC). Although it had been using drugs but still $60 \%$ lost, whereas for salmon and trout with the use of antibiotics used 63,000 -104,000 Lb.

\section{References}

Austin, B. and D. Austin. 1988. Bacterial Fish Pathogen. Ellis Hoorwood. London. Pp 250 262.

Baticados, M.C.L, C.R. Lavilla-Pitogo, E.R. CruzLazierda, L.D. dela Pena, and N.A. Sunaz. 1990. Studies on the chemical control of luminous bacteria Vibrio and rearing water. Dis. Aquat. Org., 9: 133-139.

Bjorklund, H., J. Bondestam, and G. Bylund. 1990. Residue of oxytetracycline in wild fish and sediments from fish farms. Aquaculture, 86 : 359-367.

Cobello, F.C. 2006. Heavy use of prophylactic antibiotics in aquaculture: a growing problem for human and animal health and for the environment. Environt. Microbiol., 8 (7): $1137-1144$

Horwitz, W. (Editor). 1980. Methods of the analysis of the Association of Official Analytical
Chemist, 13 thedn. Section 42.196-42.201; 42.21.12b; 42-272-42.274. AOAC, Washington, DC, pp. 719-722, 729.

Leano, E.M., V.B.M. Inglis, and I.H, Mc Rae. 1999. Antibiotic resistant of Vibrio spp. and Aeromonas spp. isolated from fish and shrimp tissues rearing water in Panay Island, Philliphinnes. UPV J. Nat. Sci., 3(1) : 23-26.

Nygaard, K., B.T. Lunestad, H. Hektoen, J.A. Berge, and V. Hormazabal. 1992. Resistance to oxytetracycline, oxolinic acid and furazolidone in bacteria from marine sediments. Aquaculture, 104 : 31-36.

Paone, S. 2000. farmed and dangerous : human health risk associated with salmon farming. www.ancientrainforest. Org. 24 des 2008.

Peterson, A, J. S.Strodl, T. Kaewmak, T. Somsirians, and A. Dalgard. 2002. Impact of Fish Farmingon Antimicrobial Resistance in a Pond Environtment. J. Applied and Environt. Micrbiol., 68(12) : 6036-6042.

Primavera, J.H., C.R. Lavilla-Pitogo, J.M. Ladja, and M. de la Pena. 1993. A survey of chemical and biological products used in intensive prawn farms in the Philiphinnes. Mar. Pollut. Bull., 26 : 35-40.

Spanggaard, B., F. Jorgensen, L. Gram, and H.H. Huss. 1993. Antibiotics resistance in bacteria isolated from three freshwater fish farms and an unpolluted stream Denmark. Aquaculture, $115: 195-207$.

Tendencia, E.A. and L.D. dela Pena. 2001. Antibiotics resistance of bacteria from shrimp ponds. Aquaculture, 195 : 193-204.

Thomson, S. 1966. Determination of oxytetracycline (Terramycine) in animal tissues. Microbiological Plate Diffusion Method Pfizer Corporation, Quality control Dept., Dallas. Texas. 